\title{
"Leading Many Sons to Glory": Historical Implications of Exclusive Language in the Epistle to the Hebrews
}

\author{
Amy Lauren Peeler
}

check for updates

Citation: Peeler, Amy Lauren. 2021. "Leading Many Sons to Glory": Historical Implications of Exclusive Language in the Epistle to the Hebrews. Religions 12: 844. https:// doi.org/10.3390/rel12100844

Academic Editor: Joel B. Green

Received: 13 August 2021

Accepted: 24 September 2021

Published: 8 October 2021

Publisher's Note: MDPI stays neutral with regard to jurisdictional claims in published maps and institutional affiliations.

Copyright: (C) 2021 by the author. Licensee MDPI, Basel, Switzerland. This article is an open access article distributed under the terms and conditions of the Creative Commons Attribution (CC BY) license (https:/ / creativecommons.org/licenses/by/ $4.0 /)$.
School of Biblical and Theological Studies, Wheaton College, Wheaton, IL 60187, USA; amy.peeler@wheaton.edu

\begin{abstract}
This study examined Hebrews' use of gender-exclusive language for the purpose of understanding the author of the Epistle's perspective on women and their role the religious community. The study used both broader historical research and exegetical analysis to support theological conclusions about Hebrews' treatment of women. Despite the use of gender-exclusive language, the epistle does not suggest a bias against women. On the contrary, in the author of Hebrews' hand, gendered language becomes a vehicle for understanding the implications of the gospel message for the Christian community.
\end{abstract}

Keywords: Hebrews; exclusive language; women; community; pedagogy; inheritance; priesthood

\section{Introduction}

The Epistle "to the Hebrews" is not a comfortable text. Familiar ideas interspersed with encouraging platitudes are not its domain. One does not cuddle up with it so much as be disciplined by it. A significant part of its discipline is the necessity of learning its cultural setting, a setting built upon the foundation of the vast and detailed narrative of Israel expressed by those living in the challenging realities of the Roman Empire.

The particular discomfort upon which this essay focuses is the discussion of women in the Epistle, or rather, the lack thereof. In comparison with some of the stark statements in the Pauline or Petrine literature (e.g., 1 Cor 11:3; 14:34-35; 1 Tim 2:11-15; 1 Pet 3:1-7), this oversight might be a welcome relief, but many interpreters have not found it so. In the first edition of the Women's Bible Commentary, for example, Mary Rose DeAngelo (1992) states: "This imagery requires women to read ourselves into the male relationship of father and son." To be ignored might be a greater slight than to be contested. A letter in which the author depicted salvation as "leading many sons to glory" (2:10), discipleship as the education of sons (12:5-11), and revelation as God speaking to sons (12:5), sounds not just archaic but exclusive to many readers in the 21st century.

That this is so, that the text is not just odd but troublesome, reveals a key feature of the New Testament as a theological text. If a scholar approaches a text simply as a historical document, as a repository of what someone thought at a particular time, the almost complete absence of women in the text would not only not disturb, but would, in fact, be expected. This author would be one among the many educated throughout time who ignored the presence and experience of women. Although some scholars approach Hebrews in this historically distant way, the majority of ecclesial readers who encounter it do not. For these readers, the author of Hebrews' words have a life beyond their original utterance. In fact, these living and active words have been shaping the communal and individual lives of readers for millennia.

One might argue that the words of Aristotle have had similar effect. I am rather confident that no matter what I might achieve in my life, Aristotle would continue to view me as a "deformed male" (Gen. An. 737 a 18), far less than perfect, an aberration, never capable of either ideal strength or virtue. More importantly, the ideas expressed through his writings have had profound impact on science, philosophy, theology, and culture 
(Aspegren 1990). His words have too shaped the way the world works, as have the words of the author of Hebrews.

There remain, however, at least two vital differences between their writings. First, I care not at all what Aristotle would have thought of me personally. Other than the broad generalities of being humans in the stream of "Western" culture, we share nothing in common and his personal opinion has zero effect on my life. Were it the case that the author of Hebrews viewed me in the same way as Aristotle, however, the impact would be much greater and more painful because we-the author of Hebrews and I-are part of the same community. United across vast distances of time, geography, and culture, we stand together under the confession that Jesus is Lord. To put a point on it, I interpret Hebrews 12:1 to mean that I worship with him weekly because he is a member of the cloud of witnesses, the communion of saints whom my church acknowledges as singing the same song that proclaims God's holiness. If a fellow member of that choir, from the triumphant rather than the militant section, thinks I can be ignored because I am deformed as a female, that impact is something very different than the non-existent weight of what Aristotle thinks. The wounds of a stranger pale in comparison to the wounds of a brother. Indeed, for those of us who turn to Hebrews as Christian Scripture, the author of Hebrews spoke not just for himself, but for God. This is the second reason Hebrews' impact is greater than that of Aristotle. If the author of Hebrews truly ignored women and did so because of disdain, this dismissal reflects not only a particular time and culture, but also the heart of the One who created me. The stakes are high.

It is no accident that volumes of ink have been spilt in service of explicating the gendered nature of the biblical text, a cottage industry that stands as testament to the unparalleled influence of this text across history, and, for those inside the confessing community of the church, a testament that no other text matters as much.

In what follows I argue that, in fact, the author of Hebrews did not hold the same opinion of women as did Aristotle, and I will provide evidence of this assertion from the text of Hebrews. I should, however, name at the outset the conviction that stimulated my searching of the text in the first place, namely, the conviction that if this author and I claim the same Lordship of Jesus, the Son of God born of a woman (Gal 4:4; Heb 7:14), he might articulate my value as constrained by his own culture, but he should not deny my value altogether (see discussion of the failures of this standard in (Clark 1983, pp. 204-5)). Women are not as invisible in the Epistle to the Hebrews as it might first appear, because they too are included alongside sons in the Son. Before the argument, however, it is necessary to say a word about the historical method I employ.

\section{Method}

The following essay may seem ill-fitting in a volume on New Testament theology, for it spends the bulk of its words investigating the historical realities faced by women in the ancient world. The work of Joel Green influences the method employed here (Green 2011). I am not simply describing what the author of Hebrews thought in a distant and disinterested way. As I argued above, what this author says matters a great deal to women today, particularly to Christian women. Neither am I attempting to reconstruct a history behind the text so that systematic theologians and pastors can then build a theology upon it. Hebrews offers so very little regarding its historical setting; all interpreters can do is to posit plausible situations, and I do so here with particular attention to the gendered makeup of the community. My argument for the author's inclusion of women, however, stands by virtue of the words of the text no matter what the particular situation of the community might be. That being said, this community did exist in the 1st-century world, and so I conduct the historical work in the service of better understanding the text. It is my conviction that when I better understand the situation of the text, I better understand God's intent in communicating through the text, hence, I better understand its theology. Learning history births better theology. 
I argue here for two (seemingly dissonate) aspects of Hebrews in its historical setting, namely, that it elevates women, but that it does so through its use of exclusive language. The historical work both explains why Hebrews sounds so foreign and even infuriating to many contemporary readers -it was a document of its own time-but also shows the bedrock continuity between that author and contemporary Christian theology in the valuing of women, because, as stated above, the author was also a disciple of Jesus the Messiah. Theologically aimed historical work prevents both excoriating this author for a historical situatedness he did not choose as well as twisting him to be in all ways a 21st-century feminist. My success in employing the method will be up to the reader to decide.

The historical setting of Hebrews allows interpreters to formulate plausible implications of this filial language as the author of Hebrews utilizes it. I first address the presence of women in this particular assembly. Then, I sketch some of the trends regarding education, inheritance, and religion and women's degree of participation therein. Addressing this community of Christians as vié, the Greek term for son (Heb 12:5), the author exhorts his readers to participate in realms typically dominated by sons in the 1st-century world. I contend that such filial language and themes, rather than excluding women, invites them into responsibilities and benefits. Cynthis Briggs Kittredge sees a similar move, stating that Hebrews' language "emphasizes Jesus' close kinship with all human beings, not only male ones" (Kittredge 1997, p. 429). Thus, women can step into realities predominantly reserved for sons because these women are now equal members in the Son, Jesus the Messiah (Heb 3:14).

The temptation looms large to argue that Christianity was beneficial for women while Greco-Roman and Jewish religion was detrimental. This kind of simple bifurcation is as historically inaccurate as it is dangerous (Osiek 1994). Instead of claiming an exceptionally positive status for Hebrews (Hylen 2019), I illuminate a positive dimension of Hebrews' argument for women-largely underappreciated -in light of the letter's historical situatedness. Other authors and other leaders invited women, in many and various ways, into spaces dominated by males. Hebrews gives evidence of one of the communities who did so as well.

\section{The Community of the Epistle}

Some scholars of Hebrews have argued that the author of this letter addressed his exhortation to former Jewish priests, which would indicate that women were not included (Allen 2010). Most interpreters, however, have rejected this option. The author addressed the community members as the household of God (3:6) and as an assembly (10:25). Such language makes the recipients of Hebrews sound similar to other early Christian groups. The presence of women in such a setting seems quite likely, as demonstrated by the women mentioned and addressed in the New Testament (Lk 8:2-3; Acts 1:14; Rom 16; 1 Cor 16:19; Phil 4:2; 2 Tim 2:19; Phil 2) and Celsus' famous comment that Christianity was for "women and children" (Origen 1994, Cels. 3.44). After recognition of the complexity of the sources, Ross Shepard Kraemer (1994, p. 131) carefully concludes, "[W]omen constituted a significant presence in the Jesus Movement". In fact, Mary Ann Beavis and HyeRan Kim-Cragg draw from research on contemporary New Religious Movements to argue, "Women may have made up the majority of converts, a fact obscured in the NT by the Greek preference for the masculine grammatical form" (Beavis and Kim-Cragg 2015, p. LXVI). Based on knowledge of those groups as indicated by the New Testament documents, it would be more likely that this congregation-like the others-would have included women (Lane 1991). A mixed-gender audience seems most likely, although it cannot, without the discovery of more evidence, be proven.

Moreover, with its boundary-breaking vision of time and space, the author of Hebrews envisioned this congregation as a part of a much larger group, the covenant people of the God of Israel. The text makes clear that he did place women among this larger community of faith. 
The author included the stories of at least three women in the encomium to faith (Chapter 11). In v. 11, Sarah appears as the barren one-close to death in fact ( $\vee \varepsilon v \varepsilon \kappa \rho \omega \mu \varepsilon v o v)$ through whom the promised descendants come. The grammar here has been a crux interpretum in Hebrews. It is not clear whether Sarah is the subject, hence, the one who received the power to cast seed because she regarded God as faithful, or whether she was mentioned as a parenthetical support for the hopelessness of the situation and Abraham retains the place as subject. Even if the latter was the case and Sarah was not in the foreground, she was certainly included as part of the summative all $(\pi \dot{\alpha} v \tau \varepsilon \zeta)$ in v. 13. She died $(\dot{\alpha} \pi \circ \theta v \underline{n} \sigma \kappa \omega$ in Gen 23:2; Heb 11:13), and although she did receive the promise of her son (Gen 18:9-15; 21:1-8), she did not live to see the many descendants who came from him. Moreover, it was her death that caused Abraham to mourn his standing as a sojourner ( $\pi \alpha \rho \varepsilon \pi i \delta \varepsilon \mu \mathrm{O}$ in Gen 23:4; Heb 11:13), which showed the unfulfilled promise of possessing the land. Hence, both Abraham and Sarah died without receiving their divine promise in full. In that state of necessary hope, she was among those whom the author considered as part of the community. As faithful in trust, she was among those whom God was not ashamed to be called their God (Heb 11:16).

The author also included —and even ended his list of the faithful with—Rahab. By faith, she received the spies with peace, and therefore escaped the destruction of the unfaithful (Heb 13:31). She acted in a way the author urged for the whole audience, namely, by embracing the way of peace (12:14) and bearing peaceful fruit (12:11) because it is a characteristic of God, the God of peace (13:20). She herself-with no connection to a patriarch-because of her actions, resided with the witnesses $(11: 39 ; 12: 1)$. She was included with those who did not receive their promise in full but was in some way dependent upon God's divine perfection that would happen to her along with the readers (11:40).

Finally, so too were the women who received their dead from resurrection included in this group (11:35). Commentators will see referents to the women in the prophetic literature, the mother of the Maccabean martyrs, or even the women in the gospel narratives. All of these are possible, and without more detail, it seems impossible to nail down which one group - if it is only one-the author had in mind. To my point, the author did say explicitly that there were women who received their dead, and so they too joined the cloud of witnesses.

The inclusion of these women indicates that when the author referred to their ancestors, technically their fathers, he was using this term inclusively. In 11:23, he explicitly used this word to refer to Moses' parents who hid him, which clearly included his mother and father. Every other reference to ancestors $(1: 1 ; 3: 9 ; 8: 9)$ was also utilized in a gender inclusive way, for it includes the women he has mentioned in the list of faithful in Chapter 11.

In addition to the community who lived before this audience, the communities of faith who followed them and read this letter ensured that women received its message. In this instance, beyond any claim to the author's intention to address this letter to women, I engage with the subsequent life of the text. Those early generations of readers remain important for this argument because they would have retained many of the same cultural mores of the first recipients. As this letter was copied and discussed in both the Christian East and West, if women of the early Christian movement were hearing it, by the example of Sarah, Rahab, and the resurrection women, these female auditors would have seen an invitation for their participation in these responsibilities and benefits of the sons of God.

The original audience of Hebrews, if it was like other Christian groups, likely included women. Even if not, the author affirmed that women from the history of Israel were included in the group and therefore participated in the experiences with God, articulated in filial terms. Finally, as this document spread to other Christian groups, women in those communities heard it read. With the assured inclusion of women in this broad community of Hebrews, before and after its original audience if not also among them, I may now proceed to sketch the setting in which it would have been heard, focusing upon the gendered trends of education, inheritance, and religion in the ancient world. 


\section{Gendered Dynamics in the Ancient World}

\subsection{Education}

The ancient world valued education because, as Plutarch is thought to have stated, it can lead to "sound character" (Lib. Ed. 1.1). This belief is on display in Hebrews where the education of the audience twice featured prominently in the sermon. The first instance occurred after the author introduces the name Melchizedek, with his citation of Ps 109:4 LXX (Heb 5:6-10). The story of this priest-king is a thorny one, and the author knew the entire subject of Christ's priesthood would be difficult for him to interpret because the audience had difficulty hearing. They were, the author stated bluntly, a bit dull (5:11). While all of them should have been teachers by the time the letter came to them, they were, at that time, at the learning level of infants. They needed to go back to the basics because, unable to discern good from evil, they were not prepared to choose what is right (5:13). They needed to be trained ( $\gamma \varepsilon \gamma \cup \mu v \alpha \sigma \mu \varepsilon v \alpha \alpha$, 5:14); they needed an education.

The author of Hebrews also drew a connection between training $(\gamma \nu \mu \nu \alpha \dot{\zeta}, \omega)$ and education $(\pi \alpha \iota \delta \varepsilon i \alpha)$ in Chapter 12 where the grief of $\pi \alpha \iota \delta \varepsilon^{i} \alpha$ results in righteousness for those who have been trained (Heb 12:11). This connection is found in other authors of the ancient world. The essay attributed to Demosthenes (1949) contrasts the education of philosophy to the education of practical training, but, though the content is different, both $\gamma v \mu v \alpha \dot{\zeta} \omega$ and $\pi \alpha\llcorner\delta \varepsilon i \alpha$ are seen as educative (Erot. 43). In this second instance, the author quoted a proverb that was spoken to them as sons (12:5). Focus remained upon the proverb's call for endurance of the training $(\pi \alpha \iota \delta \varepsilon i \alpha)$ they were experiencing (12:7). Other than the assertion that they were struggling against $\sin (12: 4)$, the author gave no specific example in this section of exactly what they were experiencing. It is possible that the author was speaking of the persecution they faced in the past (10:32-34) and in the present (13:3), but whatever the precise nature of the struggle, his point was to remind them that the difficulty they faced was not due to God's absence; rather, it provided evidence of God's presence. These challenges proved that God was training them so that they might partake of divine holiness (12:10) and righteousness (12:11). Whereas in Chapter 5, the author seemed to urge the audience to pursue more training - they, unlike the mature, had not had their senses trained $(\gamma \varepsilon \gamma v \mu \nu \alpha ́ \zeta \omega)$ - this passage in Chapter 12 may indicate that they simply needed to interpret correctly the training they were already experiencing.

As is evident in both of these passages, the author of Hebrews affirmed the importance of education, namely, that it is necessary, that it is difficult, and that it produces results. These ideas correlate well with educational affirmations of his time. Plato (1924), for example, spoke at length concerning the care with which parents and the state seek to educate the young toward virtue (Prot. 325-26). Likewise, Plutarch described Cato's careful and intimate education of his son, holding it up as an example (Cat. Maj. 20). Other ancients, including Aeschylus, Sophocles, Herodotus, Aesop, and Philo may also be cited as proponents of the necessity of struggle in education (Johnson 2006). The training of people into increasing maturity through the process of struggle was widely viewed as a good thing.

In the context of the 1st-century Greco-Roman world, education was a gendered affair. It is well-known that some authors decried the education of women. In addition to Juvenal's famous satire of the inappropriately educated woman at a dinner party, whose wide-ranging conversation he describes as, "Such vigorous verbiage pours from her, you'd say it was the sound of people bashing all their bowls and bells at once," (Sat. 6.434-39, $445-47)$ others too believed that education decreased women's status as virtuous wives. Lucian (1905) recounted how ridiculous and ill-effective it is for women to be educated in philosophy and literature. It is only, "one among their other embellishments if it is said that they are cultured and have an interest in philosophy" (Merc. Cond. 36). To educate a woman was an unnecessary and even negative endeavor, these authors might say.

Clearly, young men featured more prominently in educational endeavors than young women. Interpreters of the ancient world share this consensus. Commenting on the treatise attributed to Plutarch, On the Education of Children, W. Martin Bloomer concluded that a 
"gendered, class sensitive typology of bodies" underlies the preference for male education (Bloomer 2011, p. 71). Typically, boys were able to progress past the basics of grammar into the realms of rhetoric (Cribiore 2001; Pomeroy 1975), and if girls were educated, theirs was often less focused and less demanding than their male peers (Hallet 1984). Scholars of the Greek culture (Cribiore 2001) and Roman culture (Hemelrijk 2015) concur with the conclusion of Susan E. Hylen: "Women were less likely than men to be educated in this period" (Hylen 2019, p. 128).

These generalities, however, do not indicate that educated women did not exist—quite the contrary. Others authors such as Plutarch and Musonius Rufus himself argued for the education of women (Plutarch 1928; Musonius Rufus 1947b). They, like many, viewed this education as a benefit to the women and to their husbands (Pliny the Younger, Ep. 4.19.4; Quintilian, Inst. 1.1.6; Seneca, Cons. Helv. 17.3-4). The iconic frescos from Pompeii ("Sappho" as well as "Paquius Proculus and His Wife") show women with books and quills and thus serve as pertinent material examples (Winsbury 2009). In the ancient world, levels of women's education differed according to time period, geographic location, and class. Indeed, Pomeroy's (1975) conclusion captured the nuances of the period: "Roman women were liberated, but compared to Roman men they were not" (p. 189). By the 1st century, more than just elite girls could receive an education, and it could progress past elementary subjects (Hemelrijk 1999). Moreover, some women participated in physical education, musical education, or philosophy, evidenced by the dedication of philosophical works to women (Hemelrijk 2015).

Exceptions to the rule of male education certainly existed, but nowhere did education reach to levels of gender equality. The education of women and men differed because the aims of education differed. The life of an elite Greco-Roman woman was aimed at marriage: "For Roman women, marriage formed the major turning point in their lives" (Hemelrijk 2015, p. 296). Even Musonius Rufus advocated for women to be educated so that they could be good at running their households (Musonius Rufus 1947a). Due to that fact, time and purpose distinguished, therefore diminished, women's education in comparison with that of men. "The absence of a well-defined aim for female education, and the early age of marriage of most Roman girls - in their mid or late teens-caused their education to be ... deeply inconsistent: taken as a whole, it lagged behind that of men" (Musonius Rufus 1947a, p. 293; Hemelrijk 2015). These differences were often justified in the context because young men were typically being trained for different vocations than young women. Everyone should be educated, but although public and private realms overlapped in the ancient world, generally the belief was that men received training for the state and women for the home.

Less testimony exists for non-elite women, but based on material evidence of workingclass women, many may have had some facility with literacy and numeracy, enough to keep business records, at most, or carve graffiti, at least. It does not seem that women were prohibited from learning such basic skills, but neither is there evidence that they did so at the same rate as men. Hemelrijk (2015, p. 295) concluded: "literate women were far outnumbered by literate men, as well as outdone by them in terms of the level of their proficiency".

Due to its heavy dependence upon Jewish culture, Hebrews demands more than a general understanding of the educational system of the time. Jewish approaches to education are quite pertinent, particularly because the letter discussed and deepened the theme of education/training.

The situation for Jewish women was much the same. Some scholars read the writings of the rabbis to conclude that Jewish women were totally excluded from learning (Archer 1983). Other evidence indicates the situation may not have been so dismal. Although Philo made derogatory statements against women in other places (Hyp. 11.14; Sly 2020), his description of the Therapeutides provides one example affirming educated women. These Jewish women lived a life devoted to prayer and study and likely received a Greek education (Contempl., pp. 87-89) (Kraemer 1994; Taylor 2006). Docu- 
ments concerning a woman named Babatha indicate that she was savvy and educated, if illiterate (Magness 2012). Furthermore, likely educated were the women denoted as $\rho \chi\llcorner\sigma u v \alpha ́ \gamma \omega \gamma$ $\zeta$ throughout the Mediterranean world, who could have read and interpreted the Scriptures (Brooten 1982). Josephus stated that women and slaves knew the Torah (C. Ap. 2.181). Even the writings of the Rabbis themselves seem more divided on the subject. One Mishnaic ruling ( $m$. Ned. 4.3) supported fathers educating their daughters (Kraemer 1994), and others said that women could become scribes ( $m$. Qidd. 4:13; $m$. Git. 2.5; Kraemer 1994). Evidence from Rabbinic writings and those certainly composed during the Second Temple period indicate that while some Jewish women did have the opportunity to become educated, that did not seem to be the widespread norm. In other words, some women were able to be educated, but not most (Leiber 2012).

In light of that reality, the author of Hebrews' lack of differentiation among his audience is worth noting. In both discussions of $\pi \alpha \iota \delta \varepsilon i \alpha$, the author issued the same call to all members of his community. The author added no caveats in Chapter 5 to who should and could be teachers. Instead, the exhortation towards maturity and even leadership in instruction went to the whole audience. William Lane (1991, p. 135) concluded, "The writer is persuaded that 'solid food' is not the privilege of a few initiates who have been exposed to deeper truths or have attained a higher level of existence, but is intended for all Christians". Hebrews 12 states that all of them have participated in a kind of training, and if they endure, they can all look forward to the same results. In fact, not to have participated in this education possibly puts one outside the Christian community (12:8). The author exhorted the whole audience to endure the same kind of challenging training that many writers of the time primarily imagined fathers employing for sons alone.

Hebrews' author posited several types of education for this community. First, he desired for them to have an intellectual education. His expectation, arising from the length of time, was that they all should be teachers (5:12). As he began by stating that his important word to them was difficult (5:11) and because he contrasted what they should know with the elementary words of God (5:12b), it seems that he wanted them to understand and be able to convey the more difficult concepts associated with belief in the Son of the God of Israel-specifically, his priesthood. This kind of learning demands endurance. Abraham displayed it (6:13-18), and Jesus lived it in the vocation of his priesthood (5:7-10), but the author worried that his auditors may not have had it yet (6:4-8). If they were going to teach others, they would need to endure in their learning to understand the complexities of God's fulfilled promises (6:13-18; 7:21; 8:6). Everyone needed a knowledge of Israel's Scriptures and traditions and a scripturally (especially cultically) informed interpretation of the Jesus event (Thompson 2008).

The education he recommended was not simply intellectual knowledge, however. They also needed to live these realities, so, second, their education took on an experiential dimension. In Chapter 5, the author stated that knowledge about the word of righteousness leads to ethical decisions (5:14). Lived learning, then, becomes the focus in Chapter 12. Those to whom he wrote were struggling against $\sin (12: 4)$, and this education was full of grief (12:11). He was urging them to learn from their experience that God had not abandoned them. Similar to Seneca (Marc. 16.1) and Musonius Rufus (39-41 Lutz) who expected both men and women to be virtuous, the author of Hebrews demanded a high degree of fortitude in the listeners. He imported no sense that women, weak in body or in mind, would not be able to rise to the same level of training.

In both theological content and lived struggle, this author wanted everyone in the congregation to be educated. By hearing "son" and being asked to participate in the $\pi \alpha \iota \delta \varepsilon i \alpha$ about and from God, women join with their male congregants in preparing neither for the state nor the home but for residence on Mount Zion (12:22-24).

Moreover, the author urged those listening to "imitate those who through faith and patience inherited the promises" (6:15). Sarah had faith in God (11:11), and was included in those who died in faith (11:13). Rahab was faithful as were the women who received 
their dead $(11: 31,35)$. The ultimate path of education is the path of faith, and this author believed that women are just as capable as men to travel that path.

\subsection{Inheritance}

Inheritance played a key role for the author of Hebrews as evidenced by its appearance as the initial attribute of the Son ("the one who inherited all things" 1:2) and a very early description of humanity ("those who are about to inherit salvation" 1:14). From that point on, inheritance took the focus of the sermon several more times. This was a particularly salient point for the author's perspective toward women for, as Beavis and Kim-Cragg posited, "From a feminist standpoint the male 'heir of all things,' is problematic in that it functions within a patrilineal legal system in which sons inherit the paternal estate" (Beavis and Kim-Cragg 2015, p. 3).

In Chapter 6, the author urged the audience to imitate those who inherit the promises. Right away, the author recounted God's promise to Abraham that he would be blessed and multiplied (from Gen 22:17) and emphasized the fact that God upheld this promise with an oath (Gen 22:16). After Abraham showed patience, the author said, he obtained the promise. God's promise of an heir to Abraham (Gen 15:4; 16:15-17) he obtained both in miraculous birth and in rescue from death through faith (Heb 6:12) and patience (Heb 6:12 and 15). The author focused upon Abraham's patience and God's faithfulness; the point being proven is that God was faithful to keep the promise and honor the oath to Abraham. For the author of Hebrews, God's interactions with Abraham had a dual purpose. They gave assurance to him, and they also give confidence to future generations, here described as the heirs of the promise (Heb 6:17). If God's oath to Abraham resulted in the attainment of a promise, God's other oath-which arguably is the oath that Jesus would be a priest in the order of Melchizedek (Ps 109:4 LXX/Heb 7:21; Johnson 2006; Cockerill 2012) -is the hope that takes the heirs inside the veil to the presence of God (6:19).

Inheritance and promise appear together again in the Chapter 9. People who had been called needed redemption for the transgressions committed under the first covenant. Jesus' death made this possible. Then, those who were called could receive the promise of an eternal inheritance (9:15). Since Jesus' blood allowed him to go into the holy place and obtain eternal redemption (9:12), this is likely the inheritance in mind here (Koester 2001). These called ones inherit the ability to be redeemed, which recalls the transition from slavery to sonship in Heb 2:14-15, entrance into the new covenant (Heb 8:8-12), and the ability to serve God with a pure conscience (9:14).

Finally, in Chapter 12, Esau provided the negative example of someone who gave up his benefits as the firstborn son, and when he did want to inherit his blessing, he was unable to do so. His tale contrasted with the readers, who had a better future as those

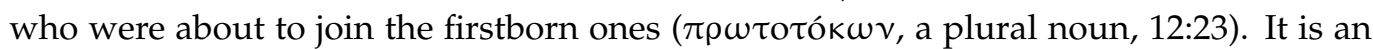
intriguing paradox that multiple saints could have the singular designation of being the "firstborn." With such a status of honor, these children would certainly inherit the blessing. These people did not follow Esau's path but inhabited the blessings of dwelling in the city of God. The author depicted all these from Israel's past as heirs of the inheritance.

In every instance, the promised inheritance involved being with God: inside the veil (6:19), in the new covenant (8:10), and on Mount Zion (12:22-24). The audience of Hebrews was exhorted to join these forebearers and take possession of their inheritance from God, which was to be in relationship with God now and dwell with God forever.

The author had cast a spiritual reality as an inheritance, a metaphor that demands contextualization. Daughters certainly could and did inherit goods and property from their fathers. Roman intestate law stipulated that if a person did not leave a will or left one that was deemed inadmissible, then children — sons and daughters no matter the ageinherited equally (Evans 1991; Walters 2003). Most Romans shuddered at the prospect of being intestate. The extant wills also show that daughters inherited. Intellectuals from Cato to Augustine regarded this as appropriate for they are some of those who made negative comment about the Lex Voconia, a law passed in 169 BC which prohibited the 
upper classes from naming daughters (even only daughters) as sole heirs (MacLachlan 2013; Evans 1991). Even under the aegis of Lex Voconia, however, daughters could still inherit, just not independently. Romans found other ways, however, to give their daughters property through the bestowal of trusts (fidecommissia) or dowries (Champlin 1991). It would not have been an unusual thing for women to assume that they would be included as heirs along with their brothers.

The legal records for Jewish women's ability to inherit are quite complicated. The biblical principle is that firstborn sons inherit a double portion, and daughters inherit only if there are no sons (Deut 21:16-17; Num 27:1-11;36:6-12). On the other hand, it is also possible to find records of Jews who made statements or actions denoting inheritance for sons and daughters, including Philo (Spec. 2.125), and the records of Babatha. The archives of Babatha and Salome Komaise, Jewish women who lived in the late 1st and early 2nd century (Oudshoorn 2007), corroborated by documents from other ancient Eastern peoples, suggest that daughters could inherit. If, however, daughters married outside their family, they lost this right (Oudshoorn 2007). Jonathan S. Milgram argued that the Tannaim develop the inclusion of daughters even more, so that daughters, even married ones, can inherit directly from their fathers. Similarly, Milgrom (2016) argued for this reality from Mishna Baba Batra 8:4. It is not clear, however, that this expansion of inheritance rights would have been in play in the 1st century.

The difference between law and lived reality, then, seems to work against the benefit of women on this point. While it is true that daughters could have inherited equally with their brothers, examples remain where daughters were given less inheritance than their brothers. It seems that fathers wanted to leave their daughters something, as the Babatha records attest, and unmarried daughters certainly took preference over anyone outside the family, but equality between sons and daughters was not the norm. Edward Champlin (1991, p. 115), in his monograph on Roman testation, closed with this summary of the evidence: "in short, all things being truly equal, one expected a daughter to receive less than a son when both were heirs".

The author of Hebrews stands among other Jewish authors of the 1st century who moralized the concept of inheritance and thereby opened it to the participation of everyone. Anyone, regardless of gender, could "inherit" the moral goods of virtue and wisdom. The Gospels' presentation of redefined family also supports an expansive and inclusive inheritance. Jesus configured family around response to God rather than biology (Mark 3:31-35; Matt 12:46-50; Luke 8:19-21). Jesus set a pattern by which anyone has invitation to come into his family, and joined with his claim of God as family, by extension his followers have God as Father as well. Jesus' words exhibit an inclusive inheritance as well. The meek will inherit the earth (Matt 5:5), those who follow him and give up family for him will inherit eternal life (Matt 19:29), and those who have done the will of God will inherit the kingdom (Matt 25:34). In the exchange with the man who inquired about how to inherit eternal life, Jesus offered the commandments and complete charity as the path (Mark 10:17-22; Luke 18:18-23).

Mark Forman highlighted the socially radical nature of Paul's use of inheritance language. First, he argued that " ... Paul is still referring to physical land, albeit extended to include the whole world, when he uses the word inheritance" (Forman 2011, p. 5), then suggested that such language "has profound socio-political significance" (Forman 2011, p. 243). Similarly, Nigel Watson (2001) argued that Paul also intended a more equal idea of inheritance between men and women in Rom 8:17. Paul explicitly extended God's relationship with sons to include daughters as well (2 Cor 6:18).

Philo knew of, and seemed to affirm, the normal practice that sons inherit property over daughters (Spec. 2.124), yet he also spoke of a blessed inheritance that comes to those who practice virtue (Her. 69, 98, 313; Fug. 17, 19; Sacr. 120, Somn. 1.175; Spec. 4.75; Virt. 79). Psalms of Solomon equates a current inheritance of a happy life with those who are devout (Pss. Sol. 14:10). Finally, The Testament of Job offers a fascinating spiritualization of inheritance for women when he granted his daughters divinely healing cords instead of 
property (T. Job 46-47). This spiritualization of inheritance occurred also in the Psalms. In Ps 15:5 (LXX) where the One who trusts in God finds the Lord as his inheritance, and in Psalm 118:111, the Psalmist inherited God's testimonies. "Inherit" becomes a term for obtaining in Wisdom literature as well, where virtue results in the inheritance of blessing and folly in the inheritance of cursing (Prov 3:35; 11:29; Sir 4:13; 6:1; 20:25; 37:26).

Hebrews makes similar moves. Since this author did envision an inheritance of a kingdom from God, and many have seen this kingdom to be material-the renewed creation-then his gender-silent assertions about inheritance stand in distinction with the legal and lived practices of inheritance in their historical setting. The author left no indication that women will participate differently or less in this inherited relationship and dwelling. All members of this congregation were fully equal co-inheritors, firstborn ones, with all those who confess Christ who have an inheritance with God in this future reality.

\subsection{Priesthood}

Hebrews uniquely proclaims Jesus as High Priest, but it also attributes priestly functions to the listeners. Most explicitly, in Chapter 10 the author exhorted the audience to go into the inner part of the holy place through the veil by means of the blood of Jesus (10:19). Chapter 6 previews this exhortation when the author assured them that God wants them to keep pursuing the hope before them, a hope that goes inside the veil (6:29). The author exhorted all the listeners to go into a section of the tabernacle that, if he was drawing his picture from the one described as accompanying the Israelites in the wilderness, only priests could approach and only the high priest could enter (Lev 16:2-34).

When they approach God's presence, they can perform the ministry of priests. $\Lambda \alpha \tau \rho \varepsilon u ́ \omega$ appears as a description of ministry of the auditors and can indicate worship in the cultic service. Having been cleansed by the blood of Christ and having pure consciences, they can turn from dead works to minister to the living God (9:14). He called them to the worship of thanksgiving for the kingdom they were receiving (12:28). Reverence and awe should characterize this worship because the God whom they serve is a consuming fire, imagery which evokes God's judgment (Deut 4:24; 9:3) and divine consumption of the whole burnt offering sacrifice (Lev 6:10; 1 Chron 21:26). In his closing instructions, the author exhorted his readers to continually offer a sacrifice of praise to God, that is, the fruit of lips that confess his name (Heb 13:15). He continued his instruction: "Do not neglect to do good and to share what you have, for such sacrifices are pleasing to God" (13:16). It is clear that he followed in a tradition in which sacrificial language applied to moral acts (Ps 50:14; 51:17; 141:2; Prov 21:3). He called his audience into ways of relating to God described as entrance into priestly realms and performance of priestly practices.

In the Greco-Roman world, women performed sacred rites and entered into the proximity of the gods. The history inherited from the Greeks is one in which women often served alongside or even exclusive of men. Female deities, at times, demanded female servants (Connelly 2007). In Roman religion, the priest was "responsible for leading the procession to the altar, offering prayers, consecrating the victim, and burning the entrails (exta) after the animal had been slaughtered [which was the focus act]," (Schultz 2006, p. 135), and in some of those situations, women could be priestesses and perform priestly actions, including being near the god. For example, Ovid recorded that women bathed the goddess Fortuna Virilis during her April festival (Fast. 4.133-40). They could also handle sacrifice (Schultz 2006). They might have assisted other male priests as in the sacrifice to the goddess Tellus during the Fordicidia festival (Fast. 4.629-40) or they might have performed the sacrifices on their own as did the Vestals in the blood sacrifice to Bona Dea (Schultz 2006). In the worship of Dionysus, for example, women served as priests and took a prominent role. Diodorus Siculus reported that the older women offered sacrifices, and Pausanias said that only the women could see the god because they performed the secret rites (Bowden 2010). Kraemer (1994, p. 88) concluded, "gender was not a determinative negative factor in attaining and executing religious offices and the attendant honors, privileges, prestige, and power accrued to those who had fulfilled such civic responsibilities". 
This is not to say that women were always equal to men in religious practices. The Vestal Virgins serve as a complex example of women's involvement in the Roman cult. Vestals were selected from leading families to guard the sacred hearth of the city. The vestals held the important task of making sure "that the Roman's public sacrifices were ritually pure and effective" (Kraemer 1994, p. 29). This vital and honored role, however, had its limitations, not only by class, but also by behavior. Women also had to remain virgins to stay in this role, thus prohibiting this honor from most women and opening the door to viewing them as something other than a typical "woman" (Sawyer 1996, p. 127). Inequality was present in other arenas as well. In the home, the wife ideally needed to be subordinate to husband, (Schultz 2006) and in the official Roman cult, they were not allowed to hold the highest office of Pontifex Maximus.

The presence of the Scriptures of Israel indicates, however, that the author of Hebrews was working (not exclusively) but primarily with a Jewish cultic model. Arising out of ancient Judaism's concepts of ritual purity, women did not serve as priests in the Jewish tabernacle or temple. The exception comes from Leontopolis, where an inscription from 28 BCE notes a Marin, a priestess. Nevertheless, Sawyer (1996, p. 75) argued, "the Leontopolis inscription is extremely rare, and far too sparse to allow us to conclude with confidence that women had any significant cultic functions within Judaism". It seems that women were involved in synagogues and in religious societies, but not as priests.

Some Jewish groups outside the temple complex would have afforded women spiritual experiences cast in priestly descriptions. Other Jews of the time articulated worship and prayer in priestly terms. Philo believed a special class existed that can approach God. He called them priests and prophets and talked of them throwing off the veil (Gig. 53-60) to come to God. He affirmed the importance of the functional priests in Israel (Migr. 92), but also imagined a larger group of Israelites carrying out priestly functions, such as being representatives for the nations (Abr. 98), and following the law (Spec. 1.243), especially in the practices of Passover (Mos. 2.224). Philo described the Therapeutae, a contemplative group which included women, in priestly terms. He compared the women with Greek priestesses by virtue of their purity (Comtempl. 8.68). He compared the simplicity of their food to the sobriety of the sacrifices of the priests $(9.73 ; 10.81,82)$. Joan E. Taylor $(2006)$ argued that such statements indicate that the Therapeutae functioned in priestly ways along with the men in their group. The Qumran documents as well describe prayer as a replacement for the sacrifices they cannot offer in the temple. Prayer was "a sacrifice offered in righteousness" (CD 11.20-21) or a "burnt offering" (Nitzan 1994, p. 285).

Along with these, Hebrews imagines prayer and worship as a priestly act open to more than just the official priests. Consequently, while Hebrews' invitation to women to come into the holy place in the presence of God shares some similarities with the cultic practices of Greco-Roman religion and the spiritual descriptions of fellow Jews, in his text, the community is invited into a realm to perform actions that in a Jewish cultic setting would dominantly be associated with men (Cohick 2009).

\section{Conclusions}

A simple reading of Hebrews, especially in its original language, seems to indicate a lack of interest in women. For those who consider this Christian Scripture, that absence is not simply an unfortunate historical reality, it could indicate disrespect from a fellow believer, and even more challenging, a divine preference for the male. Without question, the author of Hebrews employed masculine language for the congregation because it was common to use male terms to speak of mixed-gender groups. This masculine language could indicate that authors assume that males are normative and females must transform to adhere (DeConick 2011).

The Epistle, however, provides scant evidence to support that assumption. While Hebrews uses sonship language for the community, including the women, it does not issue any further demand that any women suppress their femaleness to be a part of the community. The female members of the faithful of Israel are mothers. Nor does it explicitly 
androgenize virtue. Instead, it proclaims that all can receive the benefits of the virtue of faith. The sketch of the historical nuances with regard to education, inheritance, and priesthood illuminate where the author of Hebrews fits on that map. For this writing, all-women and men-are connected to the group to whom he was writing by divine provision because they were looking forward to the "something better," the "perfection" that God will bring to them as they join the author and his audience (11:40).

The author painted a picture of this perfection in Chapter 12 which included the spirits of the righteous that have been perfected (12:23). As these women looked forward to a promise $(11: 13,39)$, a promise of perfection (11:40) by the promise-keeping God (11:11; 10:23), they were included with these perfected righteous ones. There will be women on the holy mountain of God. If they are included, that means that they have undergone the education necessary to reach perfection (5:14). As the author described this group as the assembly of the firstborn ones ( $\pi \rho \omega \tau о \tau o ́ \kappa \omega \nu)$, these women are included in that inherited place of sovereignty. Finally, in such proximity to God, they reside in a location normally reserved for priests. The author of Hebrews did include women in the educated, royal, and priestly assembly with God. For the women who listened to this sermon, the presence of these women included by the filial terms and concepts functioned as invitations that they too could be educated, inherit, and enter the sacred space along with their fellow male believers.

This author's chief motivation in the use of this language arose out of a Christological conviction. They are all-men and women-sons because they follow the same pattern of relationship with God as that inhabited by the Son. The Messiah's maleness was not denied, but neither was it the primary focus. Instead, the primary focus remained his particularly intimate relationship with God. As the addressees were sharers in Christ (3:14), they experienced training as did Jesus, they all looked forward to an inheritance as he did, and they entered sacred space as he has. The author mentioned no barriers of priestly status or ethnicity or gender for being a participant in this family. All participate in the benefits and responsibilities of the Son. Elizabeth Rundle Charles (1888), a 19th-century English writer, made just this connection. When discussing the movement through the veil in Heb 10:14, she spoke of the removal of barriers, including gender, mentioned in Gal 3:28.

While it may very well be dissonant for a contemporary audience of Hebrews, a historically informed understanding of sonship language and themes offers a redefinition of the term whereby male or female provides neither advantage nor limitation but an open invitation into an intimate and empowering relationship with God.

Funding: This research was funded by Templeton Religious Trust, grant number TRT0095/58801 and the University of St. Andrews (School of Divinity).

Conflicts of Interest: The author declares no conflict of interest.

\section{References}

Allen, David. 2010. Hebrews. NAC 35. Nashville: B\&H Publishing Group.

Archer, Léonie J. 1983. The Role of Jewish Women in Graeco-Roman Palestine. In Images of Women in Antiquity. Edited by Averil Cameron and Amélie Kuhrt. Detroit: Wayne State University Press.

Aspegren, Kerstin. 1990. The Male Woman: A Feminine Ideal in the Early Church. Stockholm: Almqvist and Wiksell, vol. 4, p. 49.

Beavis, Mary Ann, and HyeRan Kim-Cragg. 2015. Hebrews. Wisdom Commentary Series 54; Collegeville: Liturgical.

Bloomer, W. Martin. 2011. The School of Rome: Latin Studies and the Origins of Liberal Education. Berkeley: University of California Press. Bowden, Hugh. 2010. Mystery Cults of the Ancient World. Princeton: Princeton University Press.

Brooten, Bernadette J. 1982. Women Leaders in the Ancient Synagogue: Inscriptional Evidence and Background Issues. Chico: Scholars Press, pp. 27-30.

Champlin, Edward. 1991. Final Judgments: Duty and Emotion in Roman Wills, 200 B.C.-A.D. 250. Berkeley: University of California Press. Charles, Elizabeth Rundle. 1888. Within the Veil: Studies in the Epistle to the Hebrews. London: SPCK.

Clark, Elizabeth. 1983. Women in the Early Church. Collegeville: Liturgical, Message of the Fathers of the Church.

Cockerill, Gareth Lee. 2012. The Epistle to the Hebrews. Grand Rapids: Eerdmans.

Cohick, Lynn H. 2009. Women in the World of the Earliest Christians: Illuminating Ancient Ways of Life. Grand Rapids: Baker Academic.

Connelly, Joan Breton. 2007. Portrait of a Priestess: Women and Ritual in Ancient Greece. Princeton: Princeton University Press.

Cribiore, Raffaella. 2001. Gymnastics of the Mind: Greek Education in Hellenistic and Roman Egypt. Princeton: Princeton University Press. 
DeAngelo, Mary Rose. 1992. Hebrews. In Women's Bible Commentary. Edited by Carol A. Newsom and Sharon H. Ringe. Louisville: John Knox Press.

DeConick, April. 2011. Holy Misogyny: Why Sex and Gender Conflicts in the Early Church Still Matter. London: Continuum.

Demosthenes. 1949. Orations. Translated by Norman W. DeWitt, and Norman J. DeWitt. 7 vols. Cambridge: Harvard University Press.

Evans, John K. 1991. War, Women, and Children in Ancient Rome. New York: Routledge.

Forman, Mark. 2011. The Politics of Inheritance in Romans. SNTMS 148. Cambridge: Cambridge University Press.

Green, Joel B. 2011. Rethinking 'History' for Theological Interpretation. Journal of Theological Interpretation 5: 159-74.

Hallet, Judith P. 1984. Fathers and Daughters in Roman Society: Women and the Elite Family. Princeton: Princeton University Press.

Hemelrijk, Emily Ann. 1999. Matrona Docta: Educated Women in the Roman Élite from Cornelia to Julia Domna. London: Routledge.

Hemelrijk, Emily Ann. 2015. The Education of Women in Ancient Rome. In A Companion to Ancient Education. Edited by W. Martin Bloomer. Wes Sussex: Wiley \& Sons.

Hylen, Susan E. 2019. Women in the New Testament World. Oxford: Oxford University Press.

Johnson, Luke Timothy. 2006. Hebrews: A Commentary. Louisville: Westminster John Knox Press.

Kittredge, Cynthia Briggs. 1997. Hebrews. In Searching the Scriptures: A Feminist Commentary. Edited by Elisabeth Schüssler Fiorenza. New York: Crossroad, vol. 2.

Koester, Craig R. 2001. Hebrews: A New Translation with Introduction and Commentary. New Haven: Yale University Press.

Kraemer, Ross Shepard. 1994. Her Share of the Blessings: Women's Religion Among Pagans, Jews and Christians in the Greco-Roman World. New York: Oxford University Press.

Lane, William. 1991. Hebrews 1-8. WBC 47a. Nashville: Thomas Nelson.

Leiber, Laura S. 2012. Jewish Women: Texts and Contexts. In A Companion to Women in the Ancient World. Blackwell Companions to the Ancient World. Edited by Sharon L. James and Sheila Dillon. West Sussex: Wiley Blackwell, vol. 166, pp. 329-42.

Lucian. 1905. On Salaried Posts in Great Houses. In The Dependent Scholar. Translated by Francis George Fowler, and Henry Watson Fowler. Oxford: Clarendon Press.

MacLachlan, Bonnie. 2013. Women in Ancient Rome: A Sourcebook. London: Bloomsbury.

Magness, Jodi. 2012. The Archeology of the Holy Land: From the Destruction of Solomon's Temple to the Muslim Conquest. Cambridge: Cambridge University Press.

Milgrom, Jacob. 2016. From Mesopotamia to the Mishnah: Tannaitic Inheritance Law in Its Legal and Social Contexts. Tübingen: Mohr [Siebeck].

Musonius Rufus. 1947a. That Women Too Should Study Philosophy. In Musonius Rufus: "The Roman Socrates". Translated and Edited by Cora E. Lutz. New Haven: Yale University Press.

Musonius Rufus. 1947b. Should Daughters Receive the Same Education as Sons. In Musonius Rufus: "The Roman Socrates". Translated and Edited by Cora E. Lutz. New Haven: Yale University Press.

Nitzan, Bilhah. 1994. Qumran Prayer and Religious Poetry. Translated by Jonathan Chipman. Leiden: Brill.

Origen. 1994. Against Celsus. Vol. 4 of The Ante-Nicene Fathers. Translated by Alexander Roberts, and James Donaldson. Peabody: Hendrickson.

Osiek, Carolyn. 1994. Reading the Bible as Women. In The New Interpreters Bible. Edited by Leander E. Keck. Nashville: Abingdon, vol. 1, pp. 181-87.

Oudshoorn, Jacobine G. 2007. The Relationship between Roman and Local Law in the Babatha and Salome Komaise Archives. Leiden: Brill.

Plato. 1924. Protagoras. Translated by W. R. M. Lamb. 12 vols. Cambridge: Harvard University Press.

Plutarch. 1928. Moralia. Translated by Frank Cole Babbitt. 15 vols. Cambridge: Harvard University Press.

Pomeroy, Sarah B. 1975. Goddesses, Whores, Wives, and Slaves: Women in Classical Antiquity. New York: Schocken Books.

Sawyer, Deborah F. 1996. Women and Religion in First Christian Centuries. London: Routledge.

Schultz, Celia E. 2006. Women's Religious Activity in the Roman Republic. Chapel Hill: University of North Carolina Press.

Sly, Dorothy I. 2020. Philo's Perception of Women. Providence: Brown Judaic Studies.

Taylor, Joan E. 2006. Jewish Women Philosophers of First-Century Alexandria: Philo's 'Therapeutae' Reconsidered. Oxford: Oxford University Press.

Thompson, James W. 2008. Hebrews. Grand Rapids: Baker Academic.

Walters, James C. 2003. Paul, Adoption, and Inheritance. In Paul in the Greco-Roman World: A Handbook. Edited by J. Paul Sampley. Harrisburg: Trinity Press International.

Watson, Nigel. 2001. 'And If Children, then Heirs' (Rom 8:17)—Why Not Sons? ABR 49: 53-56.

Winsbury, Rex. 2009. The Roman Book: Books, Publishing, and Performance in Classical Rome. New York: Bloomsbury. 